\title{
THE RIP-OFF IS OVER!
}

\author{
by Joan N. Jukich
}

Last year a miracle happened in our language lab. Our headphone. inventory was complete. No desk carvings. The need for repairs dropped dramatically.

At first we considered it just that-a miracle-because seemingly, very little had changed. Scheduling remained the same. Nine sections of beginning French, Spanish and German students spend two of their five weekly class hours in the lab with their instructors. The advanced classes enjoy a more flexible self-scheduling. The number of open lab hours increased slightly. There was only one new faculty member among nine and the criteria for selection of lab assistants is unchanged. Physically, the fifty-console lab remains much as it has been since installed in 1964 .

Two years ago we wondered if students came armed with a tool kit. How else could they have so expertly dismantled the equipment? We learned to expect the disappearance of stereo headsets from time to time. As for graffiti, it seemed students were more anxious to make an impression on the lab than to help their lab experience make an impression on them.

What, then, were the causes of the welcome results we were observing? A pattern began to form when we examined the few changes that had occurred in the previous year.

On the theory that unfamiliarity breeds contempt, a new program designed to instruct faculty members in equipment operation was initiated. Translations of manufacturers' operating instructions, accompanied by a sketch of each machine, were distributed. Headings, describing the desired result, introduced the numbered, step-by-step procedures. The key to the success of this program was its non-technical language. In addition, experimentation was encouraged. As the faculty began to feel at ease handling the equipment, their interest in software related to their courses grew. They were soon examining film, filmstrip, recording, and slide lists as carefully as textbook catalogs. The selection of two new beginning texts in Spanish and German was made only after serious consideration of accompanying tapes. Freed from dependence on technical personnel, the faculty brought diversity to their scheduled lab hours by the addition of pertinent visual aids.

- The most important innovation, however, was the institution of a $\$ 4.00$ per quarter lab fee. Because students rightfully protest rising costs, the lab fee was fully documented. It would provide replacement of reel-to-reel recorders with cassettes, headset replacements, courserelated software, and student tapes of approved quality. The fees were 


\section{Rip $\rightarrow$ fi is over}

accepted and, with them, came an awareness of certain lab problems. This new sense of responsibility on the part of the students has contributed greatly toward the decrease in vandalism. This trend is evidently unique to the language laboratory. The library is now installing electronic devices to combat mounting book losses.

From these observations, it would seem that a more trouble-free lab operation is the result of student and faculty involvement. The lab director who jealously guards his lab equipment from the faculty is the bottleneck that prevents the effective use of the laboratory for its original purposes. The gigantic educational media center which now engulf language laboratory facilities often divorce themselves from classroom coordination by their complexity, distance, and impersonality. At most secondary schools, it would be impossible to charge a lab fee, but perhaps student responsibility could be encouraged by a rotating schedule of lab task assignments.

The idle hands that once mischievously or maliciously roamed our consoles have been stilled by interesting programs and a sense of student participation in their lab experience.

\section{NATIONAL ASSOCIATION OF LANGUAGE LABORATORY DIRECTORS NALLD JOURNAL}

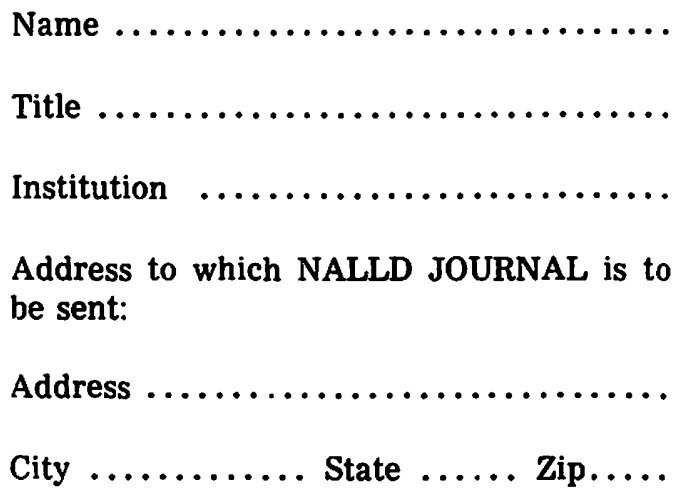

My school is paying the dues for NALLD Membership. Send the invoice to:
MEMBERSHIP APPLICATION

$\square$ New Member

Renewal

U.S.A. (50 states)

Canada

Foreign Air Mail

Student (non-voting)

Library (non-voting)

$\$ 6.00$

$\$ 7.00$

$\$ 9.00$

$\$ 4.00$

$\$ 9.00$

Return this form to:

Mr. Dale Lally

Treasurer, NALID

Language Laboratory

Marquette University

Milwaukee, Wisconsin 53233

Commercial organizations are invited to contact NALID regarding associate member. ship. 